\title{
Fungicide management in the Asian soybean rust
}

Antonio Luiz Viegas Neto ${ }^{1}$

Cristiano Márcio Alves de Souza

Bruno Fernandes Bertoncello 3

Izidro dos Santos de Lima Junior ${ }^{4}$

Lígia Maria Maraschi da Silva Piletti ${ }^{5}$

Márcio Roberto Rigotte ${ }^{6}$

\section{Abstract}

Asian soybean rust is the major crop disease and the management of the use of the fungicide is important for effective control. The objective of this work was to evaluate the management of fungicides with sequential applications to control Asian soybean rust. The experimental design used was a randomized block with four replications and eight treatments with different combinations of fungicides from the following chemical groups: triazole, strobilurin, carboxamide, and dithiocarbamate. The applications were carried out with backpack spray equipment at constant pressure $\left(\mathrm{CO}_{2}\right)$ and a spray rate of $200 \mathrm{~L} \mathrm{ha}{ }^{-1}$. The severity of rust, the area under the disease progress curve, control efficiency, mass of 1,000 grains, and productivity were evaluated. The protective fungicide mancozeb, in mixtures with systemic fungicides, were more effective for the control of Asian soybean rust than the systemic fungicides applied without the protective fungicide.

Keywords: Application technology. Phakopsora pachyrhizi. Mancozeb.

\section{Introduction}

The major disease of soybean [Glycine max (L.) Merrill] is the Asian rust caused by the fungus Phakopsora pachyrhizi H. Sydow \& Sydow, in which the first symptoms of the disease are small brown to dark brown lesions in the abaxial part of the leaves (GODOY et al., 2018). In the field, the fungus infects the leaf tissue of a wide range of hosts, its uredospores are released by an ostiole in the uredia (GOELLNER et al., 2010).

In favorable climatic conditions, Asian rust can cause damages that can vary from $10 \%$ to $90 \%$ of production (HARTMAN et al., 2015). The favorable climatic conditions for P. pachyrhizi are temperatures of $15^{\circ} \mathrm{C}$ to $25^{\circ} \mathrm{C}$ and a minimum of six hours of leaf wetness (NASCIMENTO et al., 2018; EMBRAPA, 2011).

\footnotetext{
1 Instituto Federal de Educação, Ciência e Tecnologia de Mato Grosso do Sul (IFMS). Professor EBTT. antonio.viegas@ifms.edu.br.

2 Universidade Federal da Grande Dourados (UFGD). Professor associado. csouza@ufgd.edu.br.

3 IFMS. Engenheiro Agrônomo. brunobertoncello@gmail.com.

4 IFMS. Professor EBTT. izidro.lima@ifms.edu.br.

5 IFMS. Professor EBTT. ligia.piletti@ifms.edu.br.

6 IFMS. Professor EBTT. marcio.rigotte@ifms.edu.br.
} 
According to Weirich et al. (2013), genetic resistance is the most effective and economical way to prevent damage caused by diseases in cropped plants. As there are no soybean cultivars resistant to Asian rust due to the great variability of the pathogen, disease control is difficult (NEVES; BLUM, 2013).

The use of fungicide becomes an efficient alternative for the control of the disease (GODOY et al., 2018). The application of more than one group of fungicides, with different modes of action, improves the control of the disease and prolongs the useful life of the fungicides (NASCIMENTO et al., 2018). The use of fungicides with the same mode of action creates a great risk of selecting resistant populations of the pathogen (FRAC, 2010).

The difficulty in controlling soybean rust with fungicides is becoming increasingly evident since the high adaptability and variability of the fungus has been evidenced (SCHMITZ et al., 2014). The resistance, less sensitivity of the $P$. pachyrhizi fungus to fungicides in the group of demethylation inhibitors (DMI), quinone outside inhibitors (Qol), and succinate dehydrogenase inhibitors (SDHI) has already been confirmed in Brazil (SCHMITZ et al., 2014; KLOSOWSKI et al., 2016; SIMÕES et al., 2018).

The adaptation of $P$. pachyrhizi to fungicides and its ability to overcome resistance genes show that no single solution will be able to maintain the sustainability of the crop (GODOY et al., 2016). It is necessary to develop strategies to ensure economic control of the disease, to achieve maximum yield and profitability.

The use of fungicides with multi-site action is an important strategy that can contribute to reverse the decrease in sensitivity to systemic fungicides. Fungicides with a greater spectrum of action, such as mancozeb, can be allies in controlling soybean rust (GULLINO et al., 2010). There are reports of the use of this activity to increase the action spectrum of control programs containing site-specific fungicides (GODOY et al., 2018).

In this context, the objective of this work was to evaluate the management of fungicides with sequential applications for the control of Asian soybean rust.

\section{Material and methods}

The experiment was developed in the 2018/2019 harvest at the Federal Institute of Education, Science and Technology of Mato Grosso do Sul, Ponta Porã/MS campus, located on BR 463 highway, $\mathrm{km} \mathrm{14}$, at $755 \mathrm{~m}$ of altitude. The climatic conditions of the period are shown in Figure 1 . The experimental area was prepared to adapt to the physical, chemical, and biological conditions of the soil to the soybean crop, and the basic fertilizations were made according to the soil analysis and the recommendations for the crop in the region. It was used spacing between lines of $0.45 \mathrm{~m}$, soybean cultivar M6410, a stand of 13 plants per meter, and a final population of 290,000 plants per hectare.

The experimental design was a randomized block with 4 replications, 7 treatments with fungicide applications +1 control without application (TABLE 1). The plots had 8 sowing lines of 5 meters length and a useful area of $5.4 \mathrm{~m}^{2}$. The applications were carried out a backpack spraying equipment at constant pressure $\left(\mathrm{CO}_{2}\right)$ equipped with a 3-meter nozzle bar, with AIXR 110015 spray tips, the pressure at the bar set at $350 \mathrm{kPa}$, and spray volume of $200 \mathrm{~L} \mathrm{ha}^{-1}$. 
Figure 1 - Rainfall, maximum and minimum temperatures, and relative humidity during the soybean crop cycle, in the 2018/2019 harvest in Ponta Porã/MS.

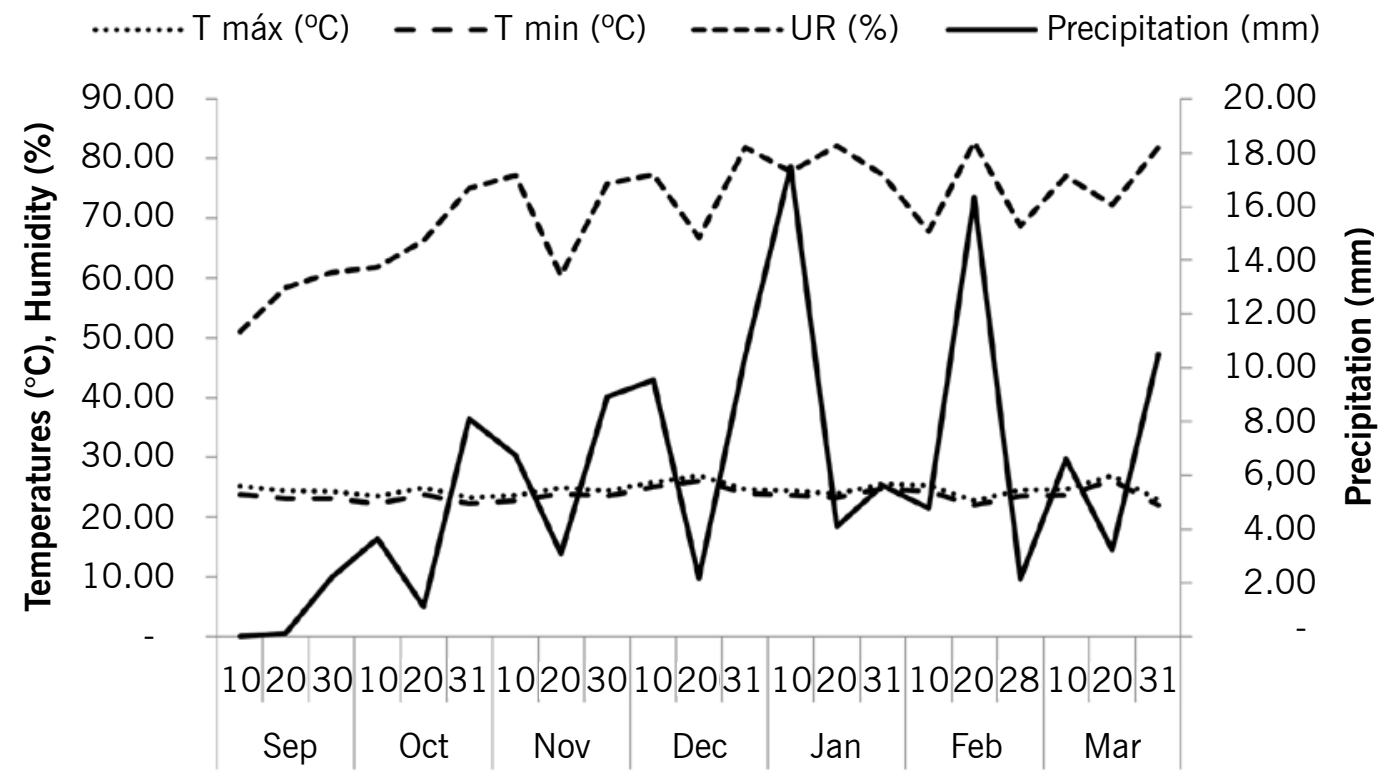

Source: INMET (2019).

Table 1 - Application periods by Fehr and Caviness's (1977) scale and the treatments used in the experiment. Ponta Porã/MS, 2021.

\begin{tabular}{|c|c|c|c|}
\hline \multirow{2}{*}{ Treatments } & \multicolumn{3}{|c|}{ Application period } \\
\hline & V8 & R1 & R4 \\
\hline $\mathrm{T} 1$ & Control & - & - \\
\hline $\mathrm{T} 2$ & $\begin{array}{l}\text { trifloxystrobin }+ \\
\text { prothioconazole }{ }^{2}\end{array}$ & $\begin{array}{l}\text { azoxystrobin }+ \\
\text { benzovindiflupir }^{1}\end{array}$ & $\begin{array}{l}\text { azoxystrobin + } \\
\text { cyproconazole }{ }^{1}\end{array}$ \\
\hline T3 & - & $\begin{array}{l}\text { azoxystrobin }+ \\
\text { benzovindiflupir }^{1}\end{array}$ & $\begin{array}{l}\text { azoxystrobin + } \\
\text { cyproconazole }^{1}\end{array}$ \\
\hline $\mathrm{T} 4$ & - & $\begin{array}{l}\text { picoxystrobin }+ \\
\text { cyproconazole }^{1}\end{array}$ & $\begin{array}{l}\text { picoxystrobin }+ \\
\text { cyproconazole }^{1}\end{array}$ \\
\hline T5 & $\begin{array}{c}\text { azoxystrobin }+ \\
\text { ciproconazol }^{1}+ \\
\text { mancozeb }\end{array}$ & $\begin{array}{l}\text { azoxystrobin + } \\
\text { benzovindiflupir }\end{array}$ & $\begin{array}{l}\text { picoxystrobin }+ \\
\text { cyproconazole }^{1}\end{array}$ \\
\hline T6 & $\begin{array}{l}\text { trifloxystrobin }+ \\
\text { prothioconazole }{ }^{2}\end{array}$ & $\begin{array}{c}\text { azoxystrobin }+ \\
\text { benzovindiflupir }^{1}+ \\
\text { mancozeb }\end{array}$ & $\begin{array}{c}\text { picoxystrobin }{ }^{+} \\
\text {cyproconazole }^{1}+ \\
\text { mancozeb }\end{array}$ \\
\hline T7 & $\begin{array}{c}\text { trifloxystrobin }+ \\
\text { prothioconazole }^{2}+ \\
\text { mancozeb }\end{array}$ & $\begin{array}{c}\text { azoxystrobin }+ \\
\text { benzovindiflupir }^{1}+ \\
\text { mancozeb }\end{array}$ & $\begin{array}{c}\text { picoxystrobin }{ }^{+} \\
\text {cyproconazole }^{1}+ \\
\text { mancozeb }\end{array}$ \\
\hline T8 & - & $\begin{array}{c}\text { azoxystrobin }+ \\
\text { benzovindiflupir }{ }^{1}+ \\
\text { mancozeb }\end{array}$ & $\begin{array}{c}\text { azoxystrobin }+ \\
\text { ciproconazol }^{1}+ \\
\text { mancozeb }^{+}\end{array}$ \\
\hline
\end{tabular}

${ }^{1}$ Adition of Nimbus $0.5 \mathrm{~L} \mathrm{ha}^{-1}$; ${ }^{2}$ aditon of Aureo $0.5 \mathrm{~L} \mathrm{ha}^{-1}$.

Source: Elaborated by the authors (2021) 
Weekly monitoring was carried out to detect Asian soybean rust through collections of 30 trifoliums from the lower and middle third of the crop. The first application was performed on December 20, 2017, phenological stage V8, in a preventive manner, without detecting the disease. The second application was carried out on January 04,2018 , phenological stage R1, in which the first signs of the disease appeared, and the third application was carried out on January 20, 2018, phenological stage R4. From the first application of the fungicide, weekly collections of 10 trefoils were removed from the lower and middle thirds of the plants in each plot. The severity of the disease, the area under the disease progress curve (AUDPC), the mass of 1,000 grains, and the yield $\left(\mathrm{kg} \mathrm{ha}^{-1}\right)$ were evaluated.

The severity of Asian rust was assessed by determining the percentage of leaf area with symptoms of the disease, using the scale proposed by Godoy et al. (2006). The evaluations were performed at $0,7,14,21,28$, and 35 days after the first application of the fungicide. Using the severity data from the last evaluation, the control efficiency (\%) of the fungicides was determined, according to Godoy et al. (2018).

Based on the data on the severity of the disease, the progress curve and the determination of the area under the disease progress curve (AUDPC) were constructed, calculated from the methodology proposed by Campbell and Madden (1990):

$$
\mathrm{AACPD}=\sum_{i=1}^{n-1}\left(\frac{y_{i}+y_{i+1}}{2}\right) \cdot\left(t_{i+1}-t_{i}\right)
$$

In which,

AUDPC - area below the disease progress curve;

$\mathrm{y}_{\mathrm{i}}$ - disease proportion in the $i^{\text {th }}$ observation;

$t_{i}$ - time in days in the $i^{\text {th }}$ observation;

$\mathrm{n}$ - total number of observations.

The harvesting of soybeans was performed by manual removal of all plants present in an area of $5.4 \mathrm{~m}^{2}$, and then the threshing was carried out. After threshing, the grains were packed in paper bags, and properly identified and stored for later manual cleaning and moisture determination. The samples were weighed and the value converted to $13 \%$ humidity, the results expressed in $\mathrm{kg} \mathrm{ha}^{-1}$. The 1,000-grain mass was obtained from three random samples of grains from each experimental plot.

The data were submitted to the normality test, using the Ryan-Joiner test, at $1 \%$ probability. Analysis of variance was performed compared by the $\mathrm{F}$ test at $5 \%$ probability. The comparisons between means were performed using the test of Tukey, at $5 \%$ probability. Cluster analysis was applied using the Ward method with the similarity measure given by the Euclidean distance, to group the treatments with fungicide applications, defining the cut distance equal to $50 \%$ of the maximum Euclidean distance.

\section{Results and discussion}

Soybean rust was first detected in the experimental area on January 04, 2018, phenological stage R1. The climatic condition is a determining factor for the appearance of soybean rust, the survival of uredospores is greatly affected by temperature and relative humidity, uredospores exposed to temperatures above $40{ }^{\circ} \mathrm{C}$ and relative humidity between $12 \%$ to $20 \%$, proved to be unfeasible 
after 4 to 6 hours (NASCIMENTO et al. , 2018). In the work carried out by Twizeyimana and Hartman (2010), spores on leaves maintained at $25^{\circ} \mathrm{C}$, with $34 \%$ relative humidity, survived for only $15 \mathrm{~h}$. Table 2 shows the summary of the analysis of variance. A significant effect of treatments was observed for AUDPC, the mass of 1,000 grains, and productivity.

Table 3 shows the results of severity, percentage of control, and AUDPC.

Table 2 - Summary of analysis of variances for the percentage of severity (SEV), the area under the disease progress curve (AUDPC), the mass of 1,000 grains $g$ (M1000), and the grain yield $\mathrm{kg} \mathrm{ha}^{-1}$ (YIELD) in the crop soybean, 2018/2019 harvest. Ponta Porã/MS, 2021.

\begin{tabular}{ccccc}
\hline FV & Sev & AUDPC & M1000 & YIELD (kg ha ${ }^{-1}$ ) \\
\hline Block & 0.92 & 21.0 & 45.2 & $649,782.9^{*}$ \\
Tret & 0.99 & $46.7^{* *}$ & $216.4^{*}$ & $750,720.2^{* *}$ \\
Residue & 0.72 & 11.4 & 63.3 & $163,914.3$ \\
\hline
\end{tabular}

${ }^{n s}$ non-significant, **, * Significant at $1 \%$ and $5 \%$ probability by the $\mathrm{F}$ test, respectively.

Source: Elaborated by the authors (2021)

Table 3 - Disease severity, efficiency in control (\%), and area under the disease progress curve (AUDPC) for each fungicide treatment in soybean crop, 2018/2019 harvest. Ponta Porã/MS, 2021.

\begin{tabular}{cccc}
\hline Treatments & Severity & Control & AUDPC \\
\hline T1 & $1.8 \mathrm{~A}$ & - & $14.5 \mathrm{~A}$ \\
T2 & $0.7 \mathrm{~A}$ & 63.9 & $5.2 \mathrm{~B}$ \\
T3 & $0.9 \mathrm{~A}$ & 49.9 & $8.9 \mathrm{AB}$ \\
T4 & $1.3 \mathrm{~A}$ & 29.7 & $7.9 \mathrm{AB}$ \\
T5 & $0.5 \mathrm{~A}$ & 70.6 & $5.2 \mathrm{~B}$ \\
T6 & $0.4 \mathrm{~A}$ & 79.6 & $4.6 \mathrm{~B}$ \\
T7 & $0.5 \mathrm{~A}$ & 75.6 & $3.8 \mathrm{~B}$ \\
T8 & $0.9 \mathrm{~A}$ & 49.6 & $7.5 \mathrm{AB}$ \\
\hline CV (\%) & 76.1 & - & 36.5 \\
\hline
\end{tabular}

* Means followed by the same letter in the columns are not statistically different by the test of Tukey at $5 \%$ probability.

T1 - Control without fungicide;

T2 - trifloxystrobin + prothioconazole at V8, azoxystrobin + benzovindiflupir at R1, azoxystrobin + cyproconazole at R4;

T3 - azoxystrobin + benzovindiflupir at R1, azoxystrobin + cyproconazole at R4;

$\mathrm{T} 4$ - picoxystrobin + cyproconazole at R1, picoxystrobin + cyproconazole at R4;

$\mathrm{T} 5$ - azoxystrobin + cyproconazole + mancozeb at V8, azoxystrobin + benzovindiflupir at R1, azoxystrobin + cyproconazole at R4;

T6 - trifloxystrobin + protioconazole at V8, azoxystrobin + benzovindiflupir + mancozeb at R1, picoxystrobin + cyproconazole + mancozeb at R4;

$\mathrm{T} 7$ - trifloxystrobin + protioconazole + mancozeb at V8, azoxystrobin + benzovindiflupir + mancozeb at R1, picoxystrobin + cyproconazole + mancozeb at R4;

T8 - azoxystrobin + benzovindiflupir + mancozeb at R1, azoxystrobin + cyproconazole + mancozeb at R4.

Source: Elaborated by the authors (2021)

The AUDPC in treatments T2, T5, T6, and T7 were significantly lower than the control. In these treatments the application of fungicide started preventively in the V8 stage and in the T3, T4, and T8 treatments, the applications started with the appearance of the first symptoms of the disease, stage 
R1. Fungicides applied preventively are recommended as the most effective strategy for controlling this disease (NAVARINI et al., 2007). Reis (2013) emphasized recommendations to soybean farmers to apply at the end of the vegetative stage, at the line-closing, which improves the deposition of the fungicide in the lower layer of the crop canopy. The treatments T5, T6, and T7 were those that showed control efficiency greater than $70 \%$.

Preventive applications of fungicides or closer to rust detection in soybean provide greater disease control than those carried out later (NASCIMENTO et al., 2018). Rios et al. (2010), when artificially inoculating soybean plants with $P$. pachyrhizi uredospore, observed reductions in the protective and healing effects of fungicides as the applications were performed farther from inoculation.

Alves and Juliatti (2018) in a work with the application of mancozeb and systemic fungicides concluded that the effect of adding protective fungicides with systemic fungicides varied according to the interaction between these molecules. However, the applications made by Alves and Juliatti (2018) started when the plants were in the R1 stage, and, in general, the preventive applications of fungicides are more efficient in controlling rust compared to eradicating applications (AUGUSTI et al., 2014), and the protective fungicides, when applied under ideal conditions, remain on the leaves and inhibit the germination of spores in a range of hosts and in a non-specific way, acting in several fungal cell sites (REIS, 2014; ZAMBOLIM et al., 2008), therefore, being more efficient when applied preventively.

Table 4 shows the 1,000-grain weight and yield.

Table 4 - One-thousand-grain mass $(\mathrm{g})$ and yield $\left(\mathrm{kg} \mathrm{ha}^{-1}\right)$ of soybean for each treatment with fungicide, 2018/2019 harvest. Ponta Porã/MS, 2021.

\begin{tabular}{ccc}
\hline Treatments & 1000-grain mass & Yield $\mathbf{~} \mathbf{k g ~ h a}^{-1} \mathbf{~}$ \\
\hline Control & $121.7 \mathrm{~B}$ & $2,130.2 \mathrm{~B}$ \\
T2 & $136.0 \mathrm{AB}$ & $2,722.9 \mathrm{AB}$ \\
T3 & $127.1 \mathrm{AB}$ & $3,047.7 \mathrm{AB}$ \\
T4 & $134.8 \mathrm{AB}$ & $2,966.7 \mathrm{AB}$ \\
T5 & $136.5 \mathrm{AB}$ & $3,307.7 \mathrm{~A}$ \\
T6 & $143.6 \mathrm{~A}$ & $3,393.6 \mathrm{~A}$ \\
T7 & $142.8 \mathrm{~A}$ & $3,265.3 \mathrm{~A}$ \\
T8 & $135.7 \mathrm{AB}$ & $3,405.3 \mathrm{~A}$ \\
\hline
\end{tabular}

CV (\%)

5.9

5.9

* Means followed by the same letter in the columns are not statistically different by the test of Tukey at $5 \%$ probability.

T1 - Control without fungicide;

$\mathrm{T} 2$ - trifloxystrobin + prothioconazole at V8, azoxystrobin + benzovindiflupir at R1, azoxystrobin + cyproconazole at R4;

T3 - azoxystrobin + benzovindiflupir at R1, azoxystrobin + cyproconazole at R4;

$\mathrm{T} 4$ - picoxystrobin + cyproconazole at R1, picoxystrobin + cyproconazole at R4;

$\mathrm{T} 5$ - azoxystrobin + cyproconazole + mancozeb at V8, azoxystrobin + benzovindiflupir at R1, azoxystrobin + cyproconazole at R4;

T6 - trifloxystrobin + protioconazole at V8, azoxystrobin + benzovindiflupir + mancozeb at R1, picoxystrobin + cyproconazole + mancozeb at R4;

$\mathrm{T7}$ - trifloxystrobin + protioconazole + mancozeb at V8; azoxystrobin + benzovindiflupir + mancozeb at R1; picoxystrobin + cyproconazole + mancozeb at R4;

T8 - azoxystrobin + benzovindiflupir + mancozeb at R1, azoxystrobin + cyproconazole + mancozeb at R4.

Source: Elaborated by the authors (2021) 
The treatments T6 and T7 were statistically superior for the control for 1,000-grain mass and treatments T5, T6, T7, and T8 were superior to the control for yield. Protective fungicide mancozeb was added to these treatments.

Mancozeb is one of the most extensively used non-systemic fungicides in the world, with a multi-site mechanism of action (GULLINO et al., 2010). Protective fungicides, such as mancozeb, have been used in the anti-resistance management of Asian soybean rust (GODOY et al., 2018). In the experiment, the application of mancozeb in a preventive manner or in the detection of the disease, in mixtures with systemic fungicides, showed less reduction in yield.

Table 5 shows the Euclidean distances among the seven treatments that received fungicide applications to control soybean rust.

Table 5 - Euclidian distance among the seven treatments with fungicide applications for the control of soybean rust. Ponta Porã/MS, 2021.

\begin{tabular}{cccccccc}
\hline & T2 & T3 & T4 & T5 & T6 & T7 & T8 \\
\hline T2 & 0 & 325 & 244 & 585 & 671 & 542 & 682 \\
T3 & & 0 & 81 & 260 & 346 & 218 & 358 \\
T4 & & 0 & 341 & 427 & 299 & 439 \\
T5 & & & 0 & 86 & 43 & 98 \\
T6 & & & & 0 & 128 & 14 \\
T7 & & & & & 0 & 140 \\
T8 & & & & & & 0 \\
\hline
\end{tabular}

T1 - Control without fungicide;

T2 - trifloxystrobin + prothioconazole at V8, azoxystrobin + benzovindiflupir at R1, azoxystrobin + cyproconazole at R4;

T3 - azoxystrobin + benzovindiflupir at R1, azoxystrobin + cyproconazole at R4;

$\mathrm{T} 4$ - picoxystrobin + cyproconazole at R1, picoxystrobin + cyproconazole at R4;

$\mathrm{T} 5$ - azoxystrobin + cyproconazole + mancozeb at V8, azoxystrobin + benzovindiflupir at R1, azoxystrobin + cyproconazole at R4;

T6 - trifloxystrobin + protioconazole at V8, azoxystrobin + benzovindiflupir + mancozeb at R1, picoxystrobin + cyproconazole + mancozeb at R4;

T7 - trifloxystrobin + protioconazole + mancozeb at V8; azoxystrobin + benzovindiflupir + mancozeb at R1; picoxystrobin + cyproconazole + mancozeb at R4;

T8 - azoxystrobin + benzovindiflupir + mancozeb at R1, azoxystrobin + cyproconazole + mancozeb at R4.

Source: Elaborated by the authors (2021)

It can be seen in Figure 2 the cluster analysis using the Ward method with the similarity measure given by the Euclidean distance. Treatments T5, T6, T7, and T8 formed group 1 (G1), while treatments T2, T3, and T4 formed group 2 (G2). 
Figure 2 - Dendrogram showing the hierarchy of seven-treatment groups with fungicide application in the soybean crop -2018/2019 harvest. Ponta Porã/MS, 2021.

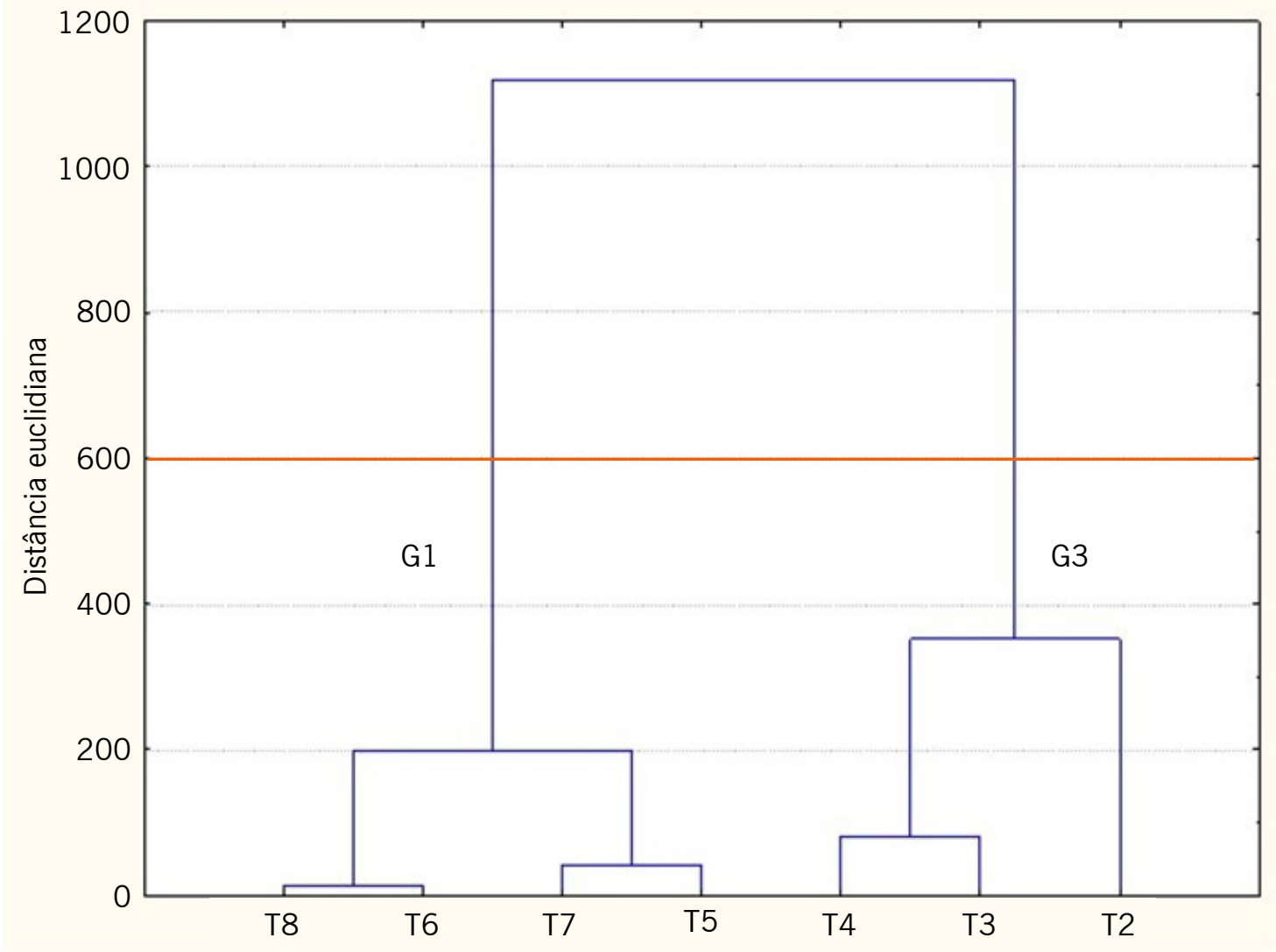

Source: Elaborated by the authors (2021)

The treatments in group 1 achieved the best results. Also, they were the treatments that had the addition of protective fungicide mancozeb, even the T8 treatment, in which the application started in $\mathrm{R} 1$, after the identification of the disease (FIGURE 2). The association of mancozeb with triazole and strobilurin fungicides has a synergistic or additive action (MARQUES, 2017).

\section{Conclusions}

Mancozeb protective fungicide in mixtures with systemic fungicides was more effective for the control of Asian soybean rust than applications of only systemic fungicides.

\section{Manejo de fungicidas no controle da ferrugem asiática da soja}

\section{Resumo}

A ferrugem asiática da soja é a principal doença da cultura, e o manejo no uso de fungicidas é importante para se ter um controle eficiente. O objetivo do trabalho foi avaliar o manejo de fungicidas com aplicações sequenciais para o controle da ferrugem asiática da soja. 0 delineamento experimental utilizado foi em blocos ao acaso com quatro repetições e oito tratamentos com diferentes combinações de fungicidas dos grupos químicos: triazol, estrobilurina, carboxamida e ditiocarbamato. As aplicações 
foram realizadas com um equipamento de pulverização costal à pressão constante $\left(\mathrm{CO}_{2}\right)$ e volume de calda de $200 \mathrm{~L} \mathrm{ha}^{-1}$. Foram avaliadas a severidade da ferrugem, área abaixo da curva de progresso da doença (AACPD), eficiência do controle, massa de 1.000 grãos e produtividade. 0 fungicida protetor mancozebe em misturas com fungicidas sistêmicos foram mais eficazes para o controle da ferrugem asiática da soja do que fungicidas sistêmicos aplicados sem o fungicida protetor.

Palavras-chave: Tecnologia de aplicação. Phakopsora pachyrhizi. Mancozebe.

\section{References}

ALVES, V. M.; JULIATTI, F. C. Fungicidas no manejo da ferrugem da soja, processos fisiológicos e produtividade da cultura. Summa Phytopathologica, Botucatu, v. 44, n. 3, p. 245-251, 2018.

AUGUSTI, G. R.; SARI, B. G.; COSTA, I. F. D.; RODRIGUES, J. S.; GUERRA, R. C. Aplicações preventivas e erradicantes de fungicidas no controle da ferrugem asiática da soja. Summa Phytopathologica, Botucatu, v. 40, n. 3, p. 288-289, 2014.

CAMPBELL, C. L.; MADDEN, L. V. Introduction to plant disease epidemiology. New York: John Wiley \& Sons, 1990. 655 p.

EMBRAPA, Tecnologias de produção de soja - Região central do Brasil 2012 e 2013. Londrina: Embrapa Soja (Sistema de produção 15), 261 p., 2011.

FEHR, W. R.; CAVINESS, C. E. Stage of soybeans development. Ames: lowa State University, 1977. 12p. (Special Report, 80.)

FRAC. FRAC recommendations for fungicide mixtures designed to delay resistance evolution. Jan. 2010. 7p. Disponível em: https://www.frac.info/docs/default-source/publications/frac-recommendationsfor-fungicide-mixtures/frac-recommendations-for-fungicide-mixtures---january-2010.pdf. Acesso em: 13 jan. 2021.

GODOY, C. V.; KOGA, L. J.; CANTERI, M. G. Diagrammatic Scale for Assessment of Soybean Rust Severity. Fitopatologia Brasileira, Brasília, v. 31, n. 1, 2006.

GODOY, C. V.; SEIXAS, C. D. S.; SOARES, R. M.; MARCELINO-GUIMARÃES, F. C.; MEYER, M. C.; COSTAMILAN, L. M. Asian soybean rust in Brazil: past, present, and future. Pesquisa agropecuária brasileira, Brasília, v. 51, n. 5, p. 407-421, 2016.

GODOY, C. V.; UTIAMADA, C. M.; MEYER, M. C.; CAMPOS, H. D.; LOPES, I. O. N.; DIAS, A. R.; DEUNER, C. C.; PIMENTA, C. B.; JACCOUD FILHO, D. S.; MOREIRA, E. N.; BORGES, E. P.; ANDRADE JUNIOR, E. R.; SIQUERI, F. V.; JULIATTI, F. C.; JULIATTI, F. C.; FAVERO, F.; FEKSA, H. R.; ARAÚJO JÚNIOR, I. P.; GRIGOLLI, J. F. J.; NUNES JUNIOR, J.; BELUFI, L. M. R.; CARNEIRO, L. C.; CARREGAL, L. H.; SATO, L. N.; CANTERI, M. G.; VOLF, M. R.; GOUSSAIN, M.; DIAS, M. D.; DEBORTOLI, M. P.; MARTINS, M. C.; BALARDIN, R. S.; FURLAN, S. H.; MADALOSSO, T.; CARLIN, V. J.; VENANCIO, W. S. Eficiência de fungicidas para o controle da ferrugem-asiática da soja, Phakopsora pachyrhizi, na safra 2017/2018: Resultados sumarizados dos ensaios cooperativos. Londrina: Embrapa Soja. 2018. 8p (Circular Técnica, 138). 
GOELLNER, K.; LOEHRER, M.; LANGENBACH, C.; CONRATH, E.K.; SCAFFRATH, U. Phakopsora pachyrhizi, the causal agent of Asian soybean rust. Molecular Plant Pathology, Malden, v. 11, n. 2, p. 169-177. 2010.

GULLINO, M. L.; TINIVELLA, F.; GARIBALDI, A.; KEMMITT, G. M.; BACCI, L.; SHEPPARD, B. Mancozeb, past, present and future. Plant Disease, v. 94, n. 9, p. 1076-1087, 2010.

HARTMAN, G. L.; SIKORA, E. J.; RUPE, J. C. Rust. In: HARTMAN, G. L.; RUPE, J. C.; SIKORA, E. J.; DOMIER, L. L.; DAVIS, J. A.; STEFFEY, K. L. (Ed.). Compendium of soybean diseases and pests. 5. ed. Saint Paul: APS Press, 2015. p. 56-59.

KLOSOWSKI, A. C.; MAY DE MIO, L. L.; MIESSNER, S.; RODRIGUES, R.; STAMMLER, G. Detection of the F129L mutation in the cytochrome b gene in Phakopsora pachyrhizi. Pest Management Science, Durham, North Carolina, EUA, v. 72, p. 1211-1215, 2016.

MARQUES, L. N. Mancozebe associado ao patossistema Phakopsora pachyrhizi $\times$ Glycine max: respostas fisiológicas das plantas. 2017. Tese (Doutorado em Agronomia) - Universidade de Santa Maria, Santa Maria, 2017. Disponível em: https://repositorio.ufsm.br/bitstream/handle/1/11631/Marques\%2c\%20 Leandro\%20Nascimento.pdf?sequence=1\&isAllowed=y. Acesso em: 04 ago. 2020.

NASCIMENTO, J. M.; GAVASSONI, W. L.; BACCHI, L. M. A.; OLIVEIRA, J. L.; LABORDE, M. C.; PONTIM, B. C. A.; MENDES, M. P. Manejo da ferrugem asiática da soja com aplicações de fungicidas iniciadas na detecção do patógeno ou posteriores. Agrarian, Dourados, v. 11, n. 39, p. 42-49, 2018.

NAVARINI, L. DALLAGNOL, L. J.; BALARDIN, R. S.; MOREIRA, M. T.; MENEGHETTI, R. C.; MADALOSSO, M. G. Controle Químico da Ferrugem Asiática (Phakopsora pachyrhizi Sidow) na cultura da soja. Summa Phytopathologica, Botucatu, v. 33, n. 2, p. 182-186, 2007.

NEVES, J. S.; BLUM, L. E. B. Influência de fungicidas e fosfito de potássio no controle da ferrugem asiática e na produtividade da soja. Revista Caatinga, Mossoró, v. 2, n. 1, p. 75-82, 2013.

REIS, E. M. Redução da sensibilidade de Phakopsora pachyrhizi a fungicidas e estratégia para retomar eficiência de controle. Revista Plantio Direto, Passo Fundo, v. 21, n. 141, p. 21-27, 2014.

REIS, E. M. Critério preventivo. In: REIS, E. M. Indicadores do momento para a aplicação de fungicidas visando ao controle de doenças nas culturas da soja e do trigo. Berthier: Passso Fundo, p. 67-76, 2013.

RIOS, J. A.; ZAMBORLIM, L.; DUARTE, H. S. S.; LOPES, J. P.; NOGUEIRA JUNIOR, A. F. Efeito protetor e curativo do epoxiconazole mais piraclostrobina no controle da ferrugem asiática da soja. Revista Tropica - Ciências Agrárias e Biológicas, v. 4, n. 2, p. 3-7, 2010.

SCHMITZ, H. K.; MEDEIROS, A. C.; CRAIG, I. R.; STAMMLER, G. Sensitivity of Phakopsora pachyrhizi towards quinone-outsideinhibitors and demethylation-inhibitors, and corresponding resistance mechanisms. Pest Management Science, v. 7, p. 378-88, 2014. 
SIMÕES, K.; HAWLIK, A.; REHFUS, A.; GAVA, F.; STAMMLER, G. First detection of a SDH variant with reduced SDHI sensitivity in Phakopsora pachyrhizi. Journal of Plant Diseases and Protection, Berlin, v. 125, p. 21-26, 2018.

TWIZEYIMANA, M.; HARTMAN, G.L. Culturing Phakopsora pachyrhizi on detached leaves and urediniospore survival at different temperatures and relative humidities. Plant Disease, St Paul, v. 94 , n. 12 , p. 1453-1460, 2010.

ZAMBOLIM, L.; PICANÇO, M. C.; SILVA, A. A.; FERREIRA, L. R.; FERREIRA, F. A.; JeSUS, J. W. C. Produtos fitossanitários (fungicidas, inseticidas, acaricidas e herbicidas). Viçosa: UFV, 2008. 652p.

WEIRICH, P. H. W.; FORNARI, A. J.; BAUER, F. C.; JUSTINO, A.; GARCIA, L. C. Aplicação de fungicidas em soja com barra de arrasto. Engenharia Agrícola, Jaboticabal, v. 33, n. 4, p. 876-882, 2013.

Received: April 7, 2020

Accepted: August 5, 2020 